\title{
Present-day and future tectonic underplating in the western Swiss Alps: reconciliation of basement/wrench-faulting and décollement folding of the Jura and Molasse basin in the Alpine foreland
}

\author{
Jon Mosar* \\ Geological Survey of Norway - NGU, Leiv Eirikssons vei 39, 7491 Trondheim, Norway
}

Received 14 June 1999; revised version received 21 September 1999; accepted 22 September 1999

\begin{abstract}
The western Alps form a geodynamically active mountain belt showing the typical features of an evolving orogenic wedge with its pro-wedge geometry to the NNW and its retro-wedge structures to the SSE. Renewed tectonic underplating of European continental crust occurred after the orogenic wedge underwent major dynamic disequilibrium following the break-off of the southward subducting slab of the European passive margin. The most important of these basement imbricates are the Mont-Blanc-Aiguilles Rouges and Gastern-Aar crystalline massifs, also forming the Alps' highest mountains. The upper plate-present-day orogenic wedge of the western Alps includes the Molasse basin and the Jura fold-and-thrust belt, both decoupled from the basement over a basal décollement surface. The overall geometry of this wedge appears to be strongly unstable according to simple wedge models. In its attempt to regain stability, out-of-sequence thrusts form in the existing basement nappes; but also new basement nappes should develop beneath the southern portion of the Molasse basin. New out-of-sequence thrusts in the cover, trigger higher than average uplift rates concentrated around the newly forming structures and are accompanied by a concentration of earthquakes. Tectonic underplating is further corroborated by neotectonics and the tectonic structures observed in the Préalpes, Molasse basin and Jura. Similarly, uplift rates, and earthquakes along the southern edge of the Jura mountains seem to witness the development of a new/incipient basement nappe at depth (partial inversion of former Permo-Carboniferous grabens in the basement). A possible spatial coincidence of areas with strong earthquake activity and zones with uplift rates above surrounding values, suggest a common mechanism for their origin in the western Swiss Alpine foreland. Combined with information from basement geometry and wedge dynamics it is proposed that the common mechanism is the development of basement imbricates by tectonic underplating. The proposed model for ongoing and possible future tectonic underplating beneath an active Alpine orogenic wedge also allows to reconcile the models of basement/wrench-faulting in the Molasse basin and Jura with the distant push theory, where the Molasse basin and Jura develop over a basal décollement horizon.
\end{abstract}

Keywords: tectonics; underthrust faults; Western Alps; Prealps; Molasse Basin; Jura Mountains; uplifts; earthquakes; imbricate tectonics

\footnotetext{
$\bar{*}$ Tel.: +47 73 904440; Fax: +47 73 921620; E-mail: jon.mosar@ngu.no
} 


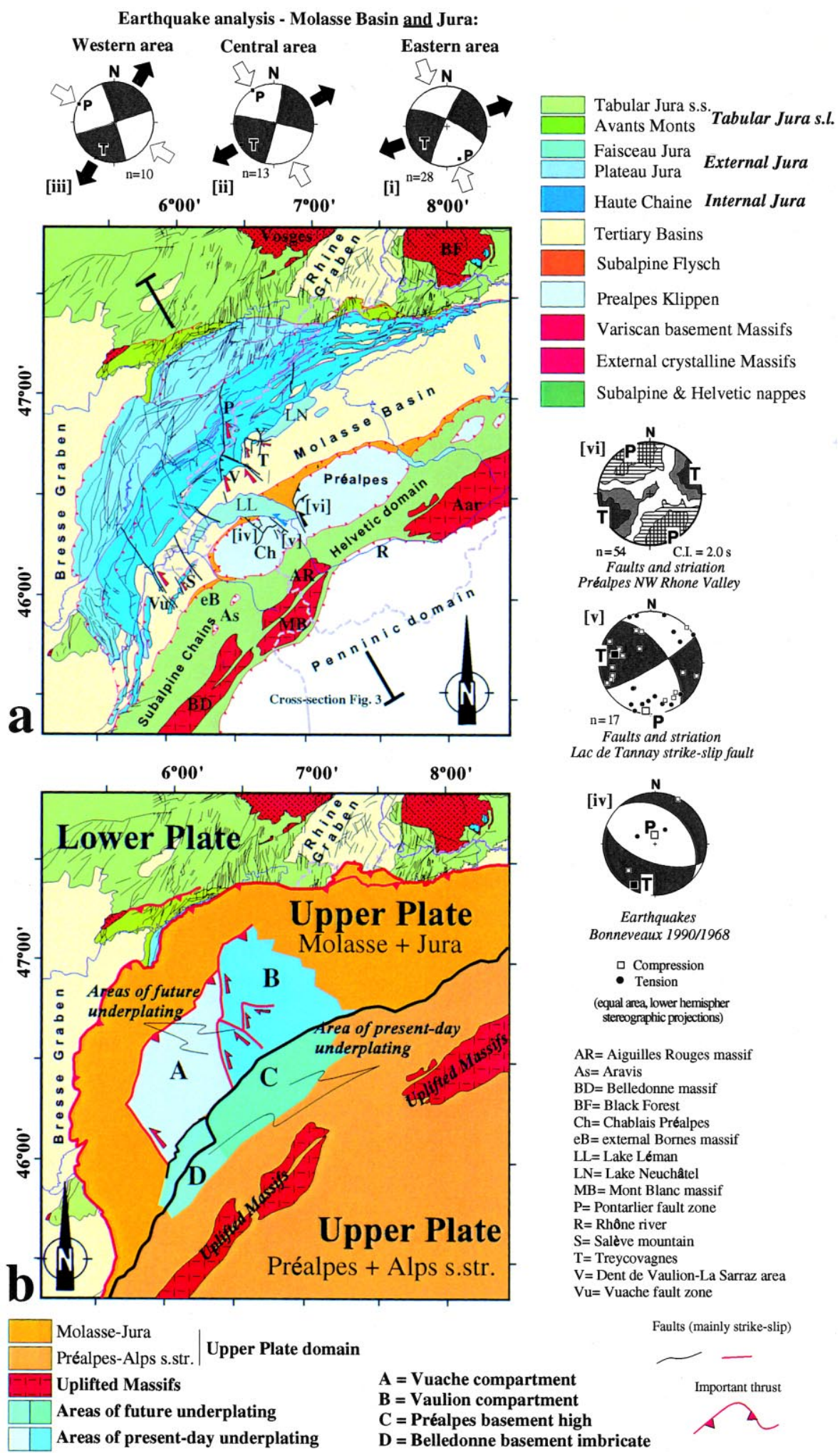




\section{Introduction}

The Alpine orogen comprises a stack of strongly deformed basement and cover nappes (Figs. 1-3) as well as pieces of oceanic floor that progressively accreted since Early Cretaceous times as the Alpine Tethys was consumed and destroyed in a south-dipping subduction zone and its associated accretionary prism [1-3]. The subsequent transition from subduction to collision occurred with the progressive accretion and tectonic underplating of material from terranes (e.g. Briançonnais) and from the passive margins of the Alpine Tethys. Major geodynamic changes, that eventually led to the formation of the Alpine orogen, are linked to crustal decoupling during the arrival of the unthinned Helvetic margin into the subduction zone and finally to the break-off of the subducting slab [4] around $35 \mathrm{Ma}$ [5,6], which is coincident with backfolding and backthrusting (top-to-the SE) in the Penninic/Piemont domain [2].

The orogen today forms a tapered, doubly vergent wedge geometry with a pro- and retrowedge respectively to the NNW and SSE [2,7,8] (Fig. 3). It is proposed here that the convergence in the Alpine orogenic wedge is still ongoing and that the mountain range is geodynamically active, as shown by the recent earthquakes [9-11], uplift-rates [12,13], and fission-track studies ([14] and references therein). Though presentday uplift in the Alps has been thoroughly documented [12], the cause of this uplift remains unknown. Varying depth of the Moho discontinuity below the Alps [15] and tectonic processes resulting from the convergence of Europe and Adria have been invoked (see discussion and references in [16]). Modeling of uplift as a result of isostatic rebound following the Würm Alpine deglaciation remained non-conclusive [16]. The possibility that some or even a large part of the uplift currently observed is caused by glacial isostatic rebound cannot be ruled out.

In the following I investigate the possibility that an important part of this uplift is related to on- going basement thrusting in the Alpine foreland. This study discusses recent and present-day tectonics highlighted by out-of-sequence thrusting (Préalpes [17]; Molasse basin/Salève [18]), earthquake activity, present-day uplift rates and basement topography (Fig. 2 - new compiled map) of the northern Alpine foreland of western Switzerland in the perspective of an active orogenic wedge that tries to achieve dynamic equilibrium.

Ongoing tectonic underplating and incipient, to possible future, tectonic underplating will be considered the main mechanism by which the dynamic orogen evolves. By tectonic underplating I refer to the process of accretion of material from the lower, subducting plate into the upper plate orogenic wedge. This tectonic underplating of sedimentary and/or crustal material will thicken the orogenic wedge and trigger a dynamic response in order to maintain its internal stability [19].

The Alpine foreland lies beyond the topographically prominent part formed by the external crystalline massifs and the Helvetic nappes, and extends to the north and northwest across the Préalpes klippen belt and the Molasse basin into the Jura mountain arc, as well as to the south towards the Po Plain. The frontal (northwest and west) basal thrust of the Jura décollement fold-and-thrust belt forms the most external limit of the Alpine orogenic wedge (Figs. 1 and 3c) with the youngest fold-and-thrust activity [20-22]. In this outer domain two different approaches to the development of the northern Alpine foreland, i.e. the Molasse basin and the Jura fold-and-thrust belt, have been debated [23,24]: on the one hand the autochthonous folding of the Jura cover due to basement thrusting and/or wrenchfaulting, and on the other hand the distant push folding ('Fernschub') by which the Alpine foreland (Jura and Molasse) deforms over a basal décollement horizon (see discussion and references in [20,21]). The data from studies on neotectonics and presentday tectonics discussed in this paper allow us to

Fig. 1. (a) Structural map of the northwestern Alps. Paleo-stress from earthquakes in the northwestern Alps: [i] eastern Swiss Molasse and Jura; [ii] central Molasse and Jura; [iii] western Molasse and Jura from [41]; [iv] earthquake focal mechanism solutions from [44,45] in the Préalpes; [v] fault-striation paleo-stress analysis; [vi] fault-striation paleo-stress analysis [41]. (b) Upper-plate and lower-plate configuration in the frontal northwestern Alps, with frontal thrust of the Alpine orogenic wedge in the western Alps and regions of possible incipient basement nappes. 


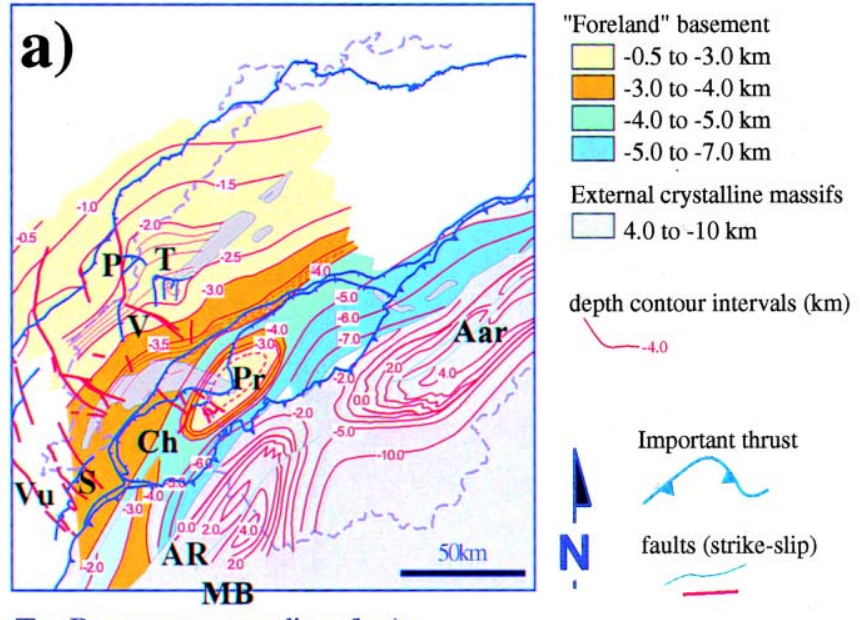

Top Basement contour lines ( $\mathrm{km})$

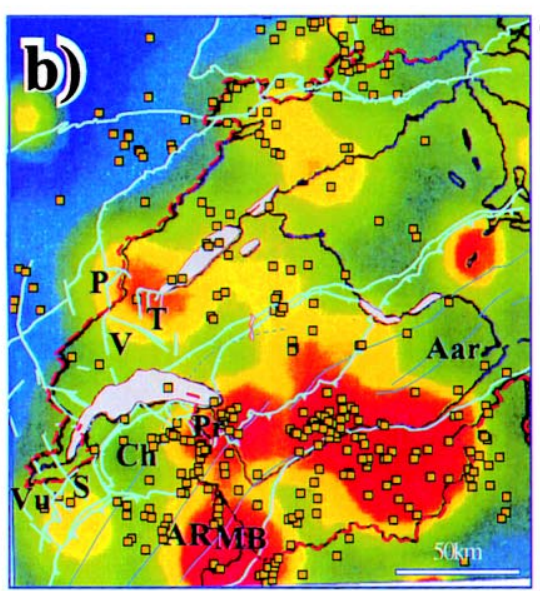

Energy release / km2 (1850-1974) Earthquakes 1990-1995

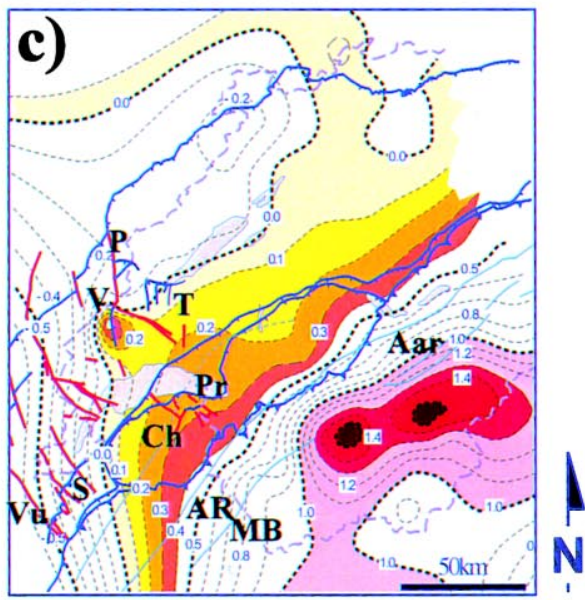

Present-day Uplift rates ( $\mathrm{mm} /$ year)

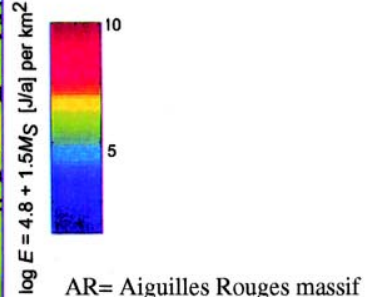

$\mathrm{As}=$ Aravis

$\mathrm{BD}=$ Belledonne massif $\mathrm{BF}=$ Black Forest

$\mathrm{Ch}=$ Chablais Préalpes $\mathrm{eB}=$ external Bornes massif

$\mathrm{LL}=$ Lake Léman

$\mathrm{LN}=$ Lake Neuchâtel

$\mathrm{MB}=$ Mont Blanc massif

N $\mathrm{P}=$ Pontarlier fault zone

$\mathrm{R}=$ Rhône river

$\mathrm{S}=$ Salève mountain

$\mathrm{T}=$ Treycovagnes

$\mathrm{V}=$ Dent de Vaulion-La Sarraz area

$\mathrm{Vu}=$ Vuache fault zone

uplift rates (mm)

$\square-0.2-0.0 \mathrm{~mm}$

$0.0-0.1 \mathrm{~mm}$

$0.1-0.2 \mathrm{~mm}$

$0.2-0.3 \mathrm{~mm}$

$0.3-0.4 \mathrm{~mm}$

$0.4-1.0 \mathrm{~mm}$

$1.0-1.3 \mathrm{~mm}$

$1.3-1.4 \mathrm{~mm}$

$1.4-1.5 \mathrm{~mm}$

$>1.5 \mathrm{~mm}$

uplift rates contours (mm)

$\because 1.4$ 
propose a model based on tectonic underplating that integrates the basement vs. cover approaches.

\section{Tectonics of the western Alps and the Jura mountains}

Nappe emplacement and backfolding in the central part of the mountain belt (Helvetics and Penninic domains) accord with material flow in a wedge ([2,7], Fig. 3b,c). The northern part of the orogen is formed by stacked cover and basement nappes. The southern part of the Alps can be considered in a transpressional stage of deformation. When the convergent component of transpression is significant, as is the case in the Alps, the retro-step-up shear may act as a preferred plane for thrusting and strike-slip movements ([25]; oblique slip may occur along a primary retroshear zone such as along the Insubric Line; Fig. 3c). The orogeny develops due to the collision of the Apulia/Adria plate with the European plate, following the subduction of the Alpine Tethys and the Valais Oceans, and involving the Adria/Apulia and Europe passive margins, but also the Briançonnais microcontinent [1,3,6,26-28]. Tectonic features in areas relevant to the interpretations of ongoing geodynamic processes are discussed hereafter:

\subsection{Jura fold-and-thrust belt}

The Jura fold-and-thrust belt forms the arcuate external northwestern and frontal part of the Alpine orogenic wedge (Fig. 1). It deformed since Late Miocene time (11 Ma) over a basal décollement present in the Lower Triassic evaporite $([20,21,29,30]$ and references therein). Much attention has been given to the large sinistral strike-slip/tear faults such as the Pontarlier fault [31] (Fig. 1a). The orientation of these faults is radial with respect to the Jura arc and changes from $\mathrm{N}-\mathrm{S}$ to almost E-W. Some tear faults extend from the Molasse basin into the Jura (such as the Vuache fault system [32] and the Dent de Vaulion fault system) and are conjugate with smaller SE-NW-striking dextral faults. These fault systems form triangular-shaped zones with frontal ramps and lateral tear faults, such as in the Treycovagnes or the Dent de Vaulion area (Fig. 1a). These faults may also act as lateral ramps and transfer zones. Whether or not these faults root in the basement beneath the basal décollement, and if they are responsible for the observed fold development [31,33] has long been debated, but is difficult to resolve from existing seismic data when vertical throw on the faults is less than $500 \mathrm{~m}$, and no larger offset has been documented yet.

It has been shown that folds and thrust in the Molasse basin and the Jura develop above a basal décollement [20-22,29,34]. The amount of shortening of up to max. $30 \mathrm{~km}$ requires thrusting above a major décollement zone rooting beneath the external crystalline basement of the Alps s.str. Thus inversion of basement grabens and/or strike-slip faults (which can account for only moderate displacement) cannot explain the observed features (see discussion in [34]). This does not exclude that some features in the cover, accommodating minor displacement $(<500$ $\mathrm{m}$ ), are related to faulting/inversion in the basement after the main folding phase.

\subsection{Basement topography under the Jura-Molasse basin and Permo-Carboniferous grabens (pertaining to the basement)}

The basement topography beneath the Jura and the Molasse basin (Fig. 2a, Fig. 3c) is smooth and dips $1^{\circ}-3^{\circ}$ towards the southeast between the Neuchâtel Jura and the Lake Léman area [20-22,29]. In the Treycovagnes area a gentle structural high develops, and below the Molasse basin near Lake Léman, the basement rises from $-4 \mathrm{~km}$ to $-2.5 \mathrm{~km}$ and merges into a structural high under the frontal Préalpes (Fig. 2a, Fig. 3c).

The high topographic relief south of the Préalpes in the Helvetic/Penninic domains is related to the important stacking of cover nappes and basement stacking/uplift which began in Oligocene time in

Fig. 2. (a) Basement morphology in the frontal portion of the western Alps. Based on various sources including industry seismic lines from the Molasse Basin and the Jura, compiled and modified from: [14,20,21,49,56]. (b) Earthquake distribution map and energy release per $\mathrm{km}^{2}$ in the western Alps (compiled from [11,43]). (c) Present-day uplift rates in mm/year in the western Alps (data from [12,57]). 


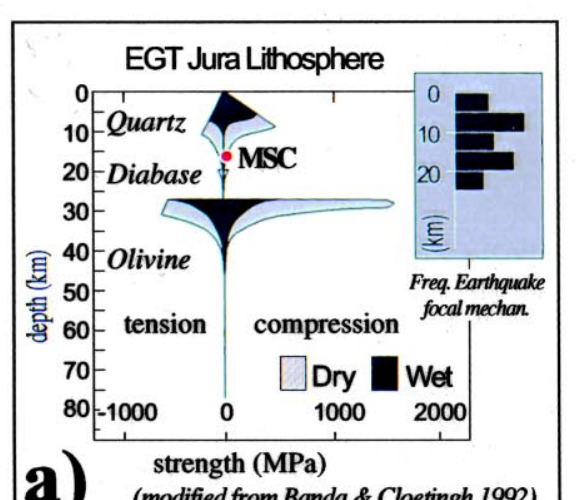

a)

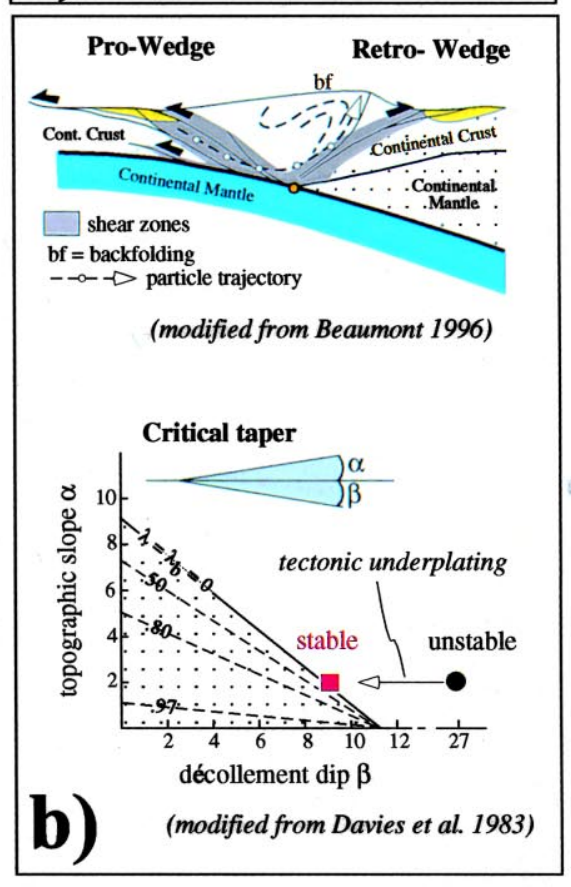

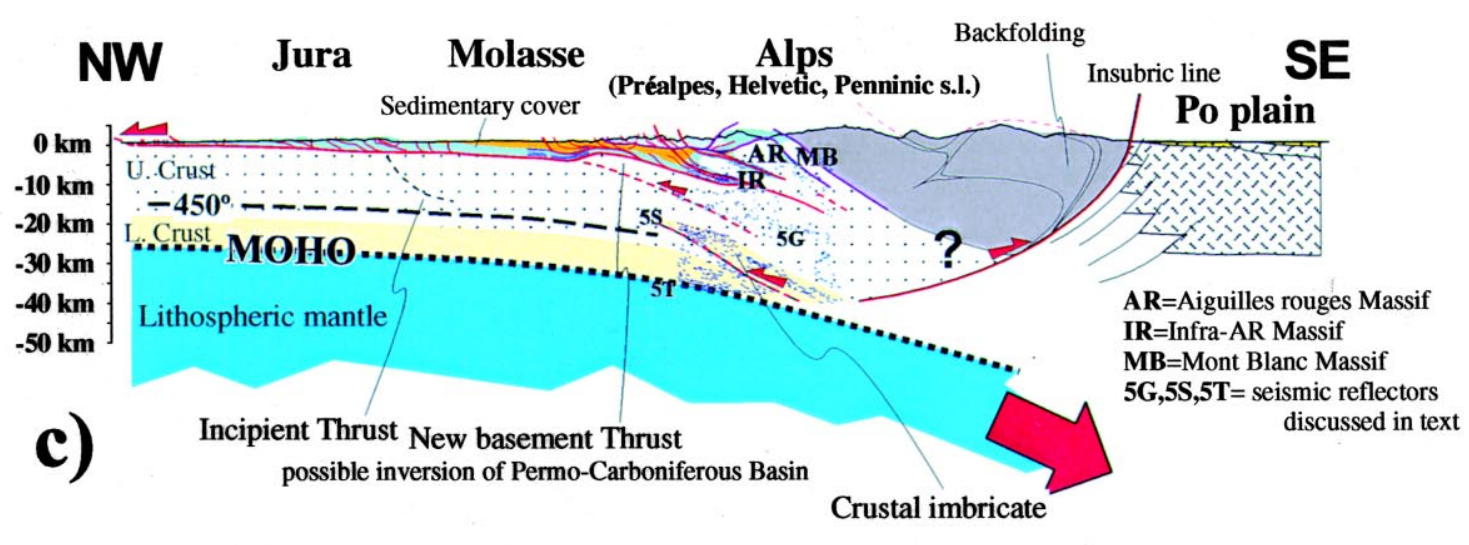
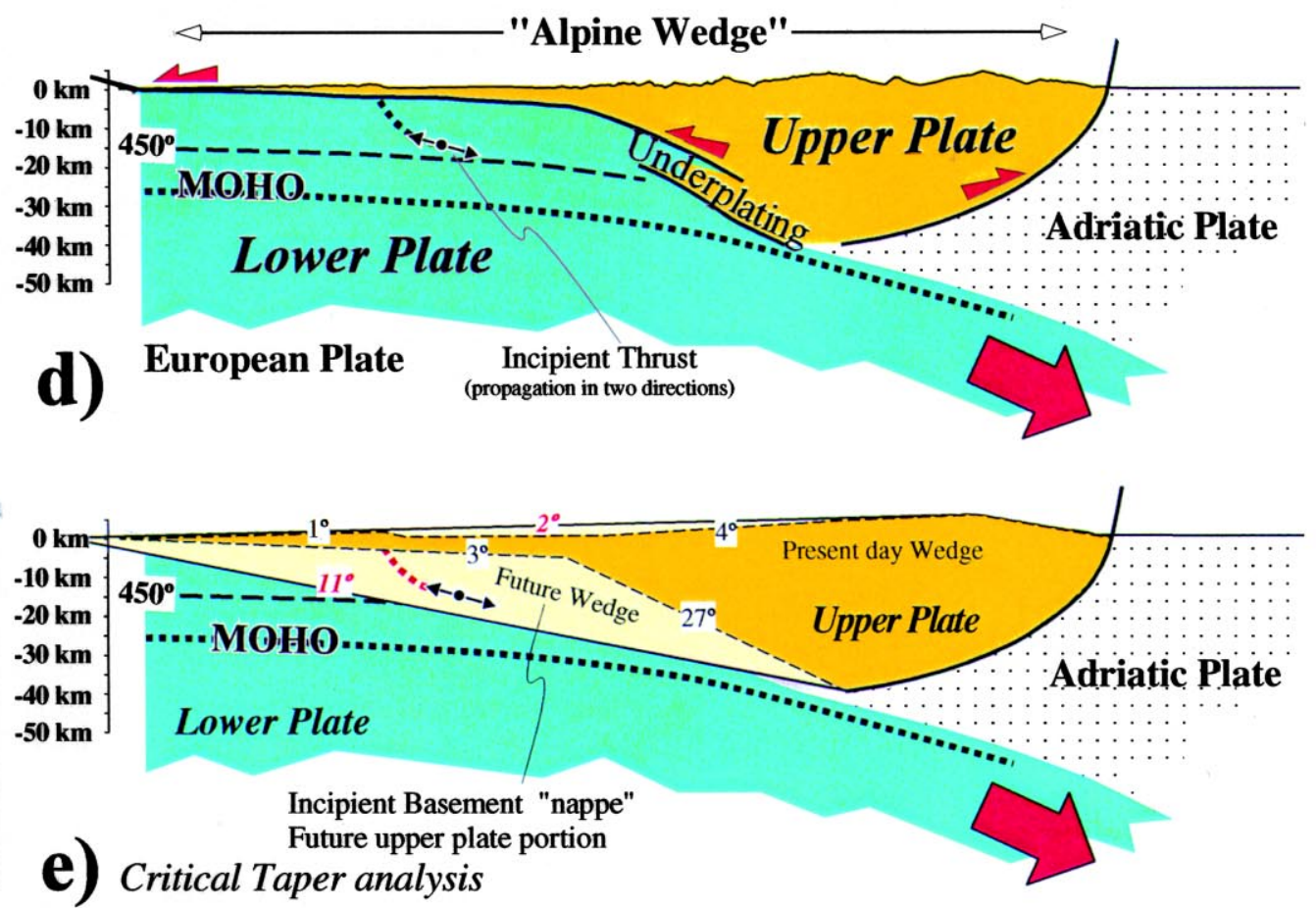

Fig. 3. (a) Strength profile of the European lithosphere in the Jura mountains [52]. $M S C=$ bottom of mechanically strong crust (ductile strength $<50 \mathrm{MPa}$ ). (b) Orogenic wedge geometry and particle trajectory (relating to the backfolding) in a dynamically active wedge [7]. Stability domain of critically tapered Coulomb wedge [51], $\lambda$ internal friction, $\lambda_{b}$ basal friction. (c) Simplified cross-section through the western Alps. Reflection data from [49] (seismic profile W5; reflectors 5S, 5T and 5G discussed in text). (d) Upper/lower plate configuration of the western Swiss Alps showing the domain of present-day tectonic underplating. (e) Critical taper geometry and location of po ssible future wedge. 
the external basement massifs (Aiguilles Rouges, Mont Blanc, Aar and Gastern massifs). The total relief ( $\sim 15 \mathrm{~km}$ with respect to the foreland) of these massifs is probably due to combined influence of stacking/tectonic underplating, continued convergence, body forces (discussion in [14,34]).

Permo-Carboniferous half-grabens are found in the folded Alpine cover-basement nappes, but also in the external Alpine domain where they show minor or no inversion. Other grabens are known from drill cores at the southern edge of the Molasse Basin near the intersection of the Chânes Subalpines and the Chablais Préalpes [35] and are suspected from seismic data [36,37]. Seismic investigation in the Jura mountains has shown the existence of such grabens in the eastern Jura [38]. Grabens seem to be absent from beneath the Molasse basin between Lake Neuchâtel and the Préalpes [21], though PermoCarboniferous sediments are known in the Dent de Vaulion-La Sarraz area.

Seismic lines show a possible inversion of a Permo-Carboniferous graben beneath the transition from the Molasse to the Préalpes klippen (Subalpine flysch) in the Rhône valley area [20-22,37]. This inversion has been related to the development of a new thrust in the European basement below the frontal Préalpes [28] (Fig. 3c).

\subsection{Tectonics of the Préalpes}

The Préalpes klippen are formed by a series of nappes of which the most important are the Préalpes Médianes. This nappe detached from its Briançonnais homeland during its incorporation into the orogenic wedge and was subsequently emplaced towards the north-northwest onto the foreland during and after the Early Oligocene (see $[1,17,28]$ and references therein). Most tectonic and all of its very low-grade metamorphic features $[39,40]$ were acquired during the incorporation into the Alpine accretionary wedge between 45 and $27 \mathrm{Ma}$ [28]. Some out-of-sequence thrusting to the north and to the west-nortwest (Préalpes and underlying Subalpine Flysch), brittle faults cutting the whole nappe structure, and a high structural relief in the Préalpes to the north and south of Lake Léman, have been linked to events post-dating the emplacement of the Préalpes onto the Alpine foreland [17,28].
Three brittle deformation events discriminate between the main emplacement and the post-emplacement tectonics in the Préalpes (Fig. 1a). (1) Deformation during pre- to syn-emplacement on the Oligocene Molasse foreland led to the formation of thrusts and tear-faults. Fault/striae sets show a NWSE compression and a horizontal NE-SW extension consistent with thrusting and strike-slip movement [41] (Fig. 1a, [vi]). (2) In the eastern Chablais Préalpes, large-scale strike-slip faults cross-cut the folds and thrusts, postdating the Oligocene emplacement of the Préalpes klippen (e.g. NW-SE sinistral Tanay-Tombeau des Allemands accident). The fault/striae analysis shows a $\mathrm{N}-\mathrm{S}$ compression and a E-W extension acting upon two main fault surfaces oriented NW-SE and NE-SW, respectively (Fig. 1a, [v]). (3) A third generation of brittle faults can be seen in the Quaternary cover in front of the Préalpes in the Chablais area [42]. The main fault described in the Quaternary sediments (BouchillonEvian accident) strikes NW-SE and has a normal NE-downward offset. Raymond et al. [42] conclude that this fault has been active into the present.

A unique feature in the western Préalpes Romandes (Switzerland) and the eastern Chablais Préalpes (Switzerland and France), is the high structural relief. The basal décollement surface of the Préalpes Médianes shows an important change in depth along strike of the regional fold trend from $-1 \mathrm{~km}$ in the western and eastern portions to $+1 \mathrm{~km}$ in the central Lake Léman area. This feature has been ascribed to a structural high in the substratum, possibly a basement nappe and/or inverted Permo-Carboniferous trough [17,28] (Fig. 3c). Its formation postdates the development of the other structures and is thus postOligocene (post-emplacement).

\section{Present-day tectonics and earthquake-activity in the western Alps}

The recent and present-day tectonic activity in the western Alpine foreland is reflected by earthquake activity, ongoing uplift, out-of-sequence thrusts (in the Préalpes and the Molasse basin: Salève) and strike-slip faults and developing basement topography (uplift of basement). 


\subsection{Uplift rates}

Recent crustal movements in the Alps [12] show that the main uplift (above $1 \mathrm{~mm} /$ year) is centered in the western Alps south of the Rhône valley, in the Penninic domain (Fig. 2c). Uplift rates slightly above those of the surrounding areas are also observed in the Swiss internal Jura, in the Dent de Vaulion area and in the external Préalpes nappes near the Lake Geneva area (Fig. 2c).

Precise leveling in the French Alps and the Jura [13] indicates regional vertical displacements. Uplift is observed in the Subalpine Chain (Belledonne, Aravis and external Bornes), in the Salève area (in the Molasse basin) as well as in the internal Jura (Fig. 1a).

\subsection{Earthquakes}

The distribution of earthquakes [11] and the associated energy release [43] shows a higher density in the central portion of the western Alps (Fig. 2b), but also in the Treycovagnes-internal Jura (Dent de Vaulion) area. Earthquake hypocenters below the northern Alpine foreland are distributed throughout the entire depth range of the crust down to $30 \mathrm{~km}$, with a higher density in the upper crust above the brittle-ductile transition estimated at $20 \mathrm{~km}$ depth (Fig. 3a). The presence of earthquakes below the brittle-ductile transition in the northern Alpine foreland is linked to the presence of high-pressure fluids [9]. A higher density of earthquakes is also observed in the Préalpes klippen around the Lake Léman area (Fig. 2b). Focal mechanisms from two earthquakes in the Bonneveaux area (eastern Chablais) in 1968 and $1990[44,45]$ show NE-SW extension along normal faults oriented NW-SE (Fig. 1a, [iv]). The stress orientation derived from earthquakes in the Molasse basin and Jura [41] shows that compression changes from a $\mathrm{N}-\mathrm{S}$ orientation in the east progressively to a NW-SE orientation in the west in the Geneva (Salève mountain)-Vuache fault area (Fig. 1a).

In the central Alps the earthquakes are related to the tectonic activity in the upper crustal nappes and the cover nappes (Fig. 3c). They are associated with the dynamic readjustments in the orogenic wedge [10]. The earthquakes in the Chablais Préalpes may be inducing the movements along steeply NE-dipping normal faults oriented NW-SE with the NE-E compartment downthrown in Quaternary and probably glacial sediments in front of the Préalpes (Bouchillion-Evian accident, [42]). Both phenomena are possibly related to the development of an inferred dome-shaped basement nappe at depth (Fig. 2a, Fig. 3c). Deformation in the crust of the Jura and Molasse basin is accommodated by sinistral and dextral movements along NNE-SSW- and NWSE-trending faults, respectively, as seen from earthquake focal mechanisms. Wrench faults and thrusts together define 'blocks' with a determined special extension. For example, the Vuache Fault system (Fig. 1a) is a major tectonic fault zone that links the Subalpine Chains to the Jura mountains across the Molasse basin [32]. Earthquake studies reveal repeated activity along this major left-lateral strikeslip fault [46,47]. Most of these earthquakes have strike-slip focal mechanisms consistent with the geologically inferred left-lateral displacement along the fault. The depth of the earthquakes is in the range of 3 to $5 \mathrm{~km}$, which places them in the upper portion of the basement, below the basal detachment that varies between 2 and $3 \mathrm{~km}[36,37]$. Whether the Vuache strike-slip fault is a tear fault/lateral ramp fault affecting the Mesozoic sedimentary cover sequence above the basal décollement only [47] or also affecting the basement $[37,46]$ cannot be resolved from the earthquake data alone.

\section{Present-day orogenic wedge in the western Alps}

Based on deep seismic investigation, geophysical data and projection of surface geology, a series of cross-sections through the western Alps have been proposed in Switzerland $[3,22,26,27]$ and in France [48]. The lithospheric scale cross-section presented here is compiled and modified from [22,28] (Fig. 3c). The deep crustal part beneath the Préalpes has been modified from [49]. The deep reflectors between 20 and $40 \mathrm{~km}$ (reflectors 5S and 5T) attributed by [49] to the lower crust, are reinterpreted as a tectonic imbricate of lower crust (Fig. 3c,d), while the reflectors at $10-18 \mathrm{~km}$ (reflector $5 \mathrm{G}$ ) are interpreted to correspond to a developing thrust zone in the upper crust. In a similar approach [2] and [49] have de- 
fined two new basement nappes under the Aiguilles Rouges-Helvetic-Préalpes (Fig. 2c). Similar imbrication of lower European crust has been described in the Alpine foreland along the Central Alps-CROP profile [50] and in the ECORS profile in France [48]. In the Alpine foreland the Moho surface is gently dipping to the southwest from some $26 \mathrm{~km}$ in the northern Jura to $40-42 \mathrm{~km}$ under the southern Préalpes [15].

If the Alps are considered from the point of view of upper- and lower-plate geometry, one has to include the Molasse basin and the Jura mountains into the upper-plate orogenic wedge (Fig. 3c,d). A critical Coulomb wedge model (Fig. 3a) can be applied to explain the geometry of an accretionary wedge and/or an orogen as a whole that deforms under the appropriate upper crustal condition [51] and can thus be applied in a first order approach to the Alps. In such a configuration the geometry of this upper plate wedge is not stable (Fig. 3e). The depth to the deepest crustal faults can be estimated by the depth of the earthquakes, the rheology/strength profile of the lithosphere [52] (Fig. 3a), and the temperature gradient in the crust (brittle-ductile transition around $450^{\circ} \mathrm{C}$ ). In the Alpine foreland, crustal faults may be generated at a depth between 15 and 20 $\mathrm{km}$ and eventually propagate upwards as well as downwards/horizontally (Fig. 3).

\section{Discussion and conclusion}

The existing data discussed here can be interpreted as the consequence of ongoing processes thrusting and faulting with associated earthquakes and uplift - linked to recent and present-day/future tectonic underplating in the northern foreland of the western Swiss Alps. Present-day tectonic underplating in the Alpine orogenic wedge is interpreted here to be a result of its unstable geometry. This may lead to the development of décollement thrusting and basement thrust/strike slip faults, which will help reacquire a stable geometry.

The spatial coincidence of areas with strong earthquake activity (high strain energy) and zones with uplift rates above surrounding values (Fig. 2b,c), suggests a common mechanism for their origin. This is further supported by the development of out-of- sequence thrusts (in the Préalpes and in the Molasse Basin). Information from basement geometry also suggests that uplift can be related to the development of basement thrusts/imbricates.

Four zones are of special interest to discuss the proposed model of active and incipient tectonic underplating in the western Swiss Alps in connection with the observed features of the neotectonics and the cover-structure (fold-faults): (1) the Préalpes in the Lake Léman area, where we observe the development of a basement high and lower crust imbricate, associated with Quaternary tectonics, high earthquake activity and a uplift rate higher than surrounding areas; (2) the Vuache strike-slip fault zone associated with recent earthquake activity; (3) the Vaulion-Pontalier area with its high uplift rate; and (4) the Treycovagnes area with its high earthquake activity and developing basement high.

These observations support the idea of active tectonics involving the basement below the main décollement level in the Molasse basin and the Jura mountains, and under the Préalpes klippen.

The ongoing growth process of the Alpine orogenic wedge will eventually lead to the tectonic underplating of new European crust. It is, however, unlikely that the crust of the lower plate (European plate) of the Alpine foreland will be involved as a whole. Rather, the crust will be cut along strike of the alpine arc into segments, most likely separated by crustal strike-slip (tear) faults such as the Vuache fault system (connecting Molasse and Jura) that link up to incipient new frontal thrust ramps (Fig. 1b). A candidate for a future basement imbricate (nappe) is the Dent de Vaulion-Treycovagne area with its triangular fault zones (Fig. 1b). The present-day uplift and earthquake activity in the Jura and in the Préalpes may then result from uplift associated with these new basement thrusts. These basement thrusts may locally invert former PermoCarboniferous basins as observed in other places in the Alps, but the amount of displacement/uplift remains modest.

The present-day geodynamic evolution of the Alps is the continuation of a process that started in the Cretaceous. It follows the major changes that occurred during the Oligocene after arrival of the thick European crust into the subduction zone and the subsequent break-off of the deeper part of the subduct- 
ing slab. The ongoing and future tectonic underplating are a consequence of these important changes. They led in the past to the final emplacement of the Préalpine klippen, to the development of the Flysch and Molasse basin in the Alpine foreland, and eventually to the development of the Jura fold-and-thrust belt. They also triggered the backfolding of the internal units, and generated magmatic intrusions along the peri-Adriatic lineament in the southern Alps. I suggest here that this dynamic process is still going on now, as the convergence of Africa and Europe continues. The history of uplift post-dating the major event is seen in the external crystalline basement of the Alps [14]. This uplift corresponds to the accretion of upper crustal material (detached above the brittle-ductile transition) from the lower European plate into the upper-plate/orogenic wedge. This tectonic underplating is coincident with backfolding in the more internal parts of the orogen (Penninic) and consistent with the displacement of material in a wedge (Fig. 3b,c). Thus the western Aar massif and the eastern Mont Blanc massif, to the southeast of the Préalpes klippen (Chablais and Préalpes Romandes), are the portion of the external crystalline massifs that have most recently crossed the isotherm of $120^{\circ} \mathrm{C}$, indicating the continuous development of basement imbricates in this area of the western Swiss Alps.

Two new crustal nappes have been postulated at depth below the Helvetic domain [2]. Their development is coeval with the most recent backthrusts in the Penninic domain. In this paper a new imbricate in the lower crust has been interpreted from previous seismic data. The tectonic underplating of this slice of lower crust is linked with the upper crustal basement imbricates and the high structural relief in the Préalpes klippen and a small possible PermoCarboniferous graben inversion beneath the southern Molasse. The stacking also explains the higher earthquake activity under the Préalpes and a higher uplift rate in the same area.

A simple first order analysis of the stability of the whole Alpine orogenic wedge in terms of critical taper (Fig. 3b,e), including the Molasse basin and the Jura fold-and-thrust belts, shows a thick southern portion with a steep basal thrust $\left(27^{\circ}\right)$ and a narrow frontal portion. The overall geometry is unstable and to maintain stable conditions implies self-similar growth by either frontal accretion or tec- tonic underplating with frontal accretion favoured by a weak décollement (the case of the Jura/Molasse décollement fold-and-thrust-belt, [53]). This can be accomplished by imbricating new basement nappes from the European upper crust and creating a new wedge geometry (with a basal thrust of some $11^{\circ}$ and a topography of some $2^{\circ}$, Fig. $3 \mathrm{~b}$,e). One such incipient thrust is probably developing beneath the Jura-Molasse transition, as indicated by earthquake activity, uplift rates and fault development. The location of the new incipient thrust that will lead to the development of a new crustal imbricate, will be at the brittle-ductile transition at the bottom of the rheologically strong upper crust. The crustal faults will generate at depth and subsequently propagate upwards and/or horizontally. There is thus no requirement for a detachment in the crust as proposed by some authors [13,54] to explain the inversion observed in the cover sequences. It is, however, unlikely that the crust of the lower plate (European plate) of the Alpine foreland will be involved as a whole. Rather the crust will be cut along strike into segments, most likely separated by crustal strike-slip (tear) faults such as the Vuache fault system that link to incipient new frontal thrust ramps. Another candidate for a future basement imbricate (nappe) is the Dent de Vaulion-Treycovagnes area with its triangular zones.

Basement imbricates have also been demonstrated to develop under the Chânes Subalpines (external Bornes and Aravis) in the French Alps to the northwest of the Belledonne massif. The tectonic activity on these basement faults is corroborated by a thrust component of earthquakes in the Bellodonne massif at a depth of some $10 \mathrm{~km}$ [55]. These authors interpret this uplift as a consequence of present-day active faulting in the crust/lithosphere.

The development of the Salève mountain faultbend fold, popping up in the middle of the Molasse basin, has been related to this new basement thrust and has also been documented by seismic activity [55].

The long standing debate opposing the 'Fernschub' hypothesis by which the Alpine foreland (Jura and Molasse) deforms over a basal décollement horizon and the theory by which folding is due to inverted basement faults and/or strike-slip faulting only, draws on data that are not mutually incompat- 
ible. On the contrary, the data, as discussed herein, support a model with a continuous geodynamic development through time of the Alpine foreland that goes on at the present day. Thus the deformation of the Jura fold-and-thrust belt and the Molasse basin over a basal décollement is followed by the development of new crustal imbricates and the associated out-of-sequence thrusting to regain a stable orogenic wedge geometry.

\section{Acknowledgements}

I would like to thank A. Sommaruga and E. Eide for their help in reviewing and improving this paper. I also would like to thank the reviewers M. Burkhard, P. Jordan and E. Kissling for their constructive comments and suggestions. [AH]

\section{References}

[1] G.M. Stampfli, J. Mosar, R. Marchant, D. Marquer, T. Baudin, G. Borel, Subduction and obduction processes in the Swiss Alps, Tectonophysics 296 (1998) 159-204.

[2] A. Escher, C. Beaumont, Formation, burial and exhumation of basement nappes at crustal scale: a geometric model based on the Western Swiss-Italian Alps, J. Struct. Geol. 19 (7) (1997) 955-974.

[3] A. Escher, J. Hunziker, H. Masson, M. Sartori, A. Steck, Geologic framework and structural evolution of the western Swiss-Italian Alps, in: O.A. Pfiffner, P. Lehner, P.Z. Heitzman, S. Mueller A. Steck (Eds.), Deep Structure of the Swiss Alps - Results from NRP 20, Birkhäuser, Basel, 1997, pp. 205-222.

[4] F. von Blanckenburg, J.H. Davies, Slab breakoff: a model for syncollisional magmatism and tectonics in the Alps, Tectonics 14 (1995) 120-131.

[5] R.H. Marchant, G.M. Stampfli, Subduction of continental crust in the Western Alps, Tectonophysics 269 (3-4) (1997) 217-235.

[6] G.M. Stampfli, R.H. Marchant, Geodynamic evolution of the Tethyan margins of the Western Alps, in: O.A. Pfiffner, P. Lehner, P.Z. Heitzman, S. Mueller, A. Steck (Eds.), Deep Structure of the Swiss Alps - Results from NRP 20, Birkhäuser, Basel, 1997, pp. 223-239.

[7] C. Beaumont, S. Ellis, J.F.Ph. Hamilton, Mechanical model for subduction-collision tectonics of Alpine-type compressional orogens, Geology 24 (8) (1996) 675-678.

[8] N. Okaya, R. Freeman, E. Kissling, S. Mueller, A lithospheric cross-section through the Swiss Alps, I: Thermokinematic modelling of the Neoalpine orogeny, Geophys. J. Int. 125 (1996) 504-518.
[9] N. Deichmann, Structural and rheological implications of lower-crustal earthquakes below northern Switzerland, Phys. Earth Planet. Inter. 69 (34) (1992) 270-280.

[10] H.R. Maurer, M. Burkhard, N. Deichmann, A.G. Green, Active tectonism in the central Alps: contrasting stress regimes north and south of the Rhône valley, Terra Nova 9 (1997) 91-94.

[11] N. Pavoni, H.R. Maurer, P. Roth, N. Deichmann, Seismicity and seismotectonics of the Swiss Alps, in: O.A. Pfiffner, P. Lehner, P.Z. Heitzman, S. Mueller, A. Steck (Eds.), Deep Structure of the Swiss Alps - Results from NRP 20, Birkhäuser, Basel, 1997, pp. 241-250.

[12] H.-G. Kahle, A. Geiger, B. Bürki, E. Gubler, U. Marti, B. Wirth, M. Rotbacher, G. Gurtner, G. Beutler, I. Bauersima, A.O. Pfiffner, Recent crustal movements, geoid and density distribution: contribution from integrated satellite and terrestrial measurements, in: O.A. Pfiffner, P. Lehner, P.Z. Heitzman, S. Mueller, A. Steck (Eds.), Deep Structure of the Swiss Alps - Results from NRP 20, Birkhäuser, Basel, 1997, pp. 251-259.

[13] F. Jouanne, G. Ménard, X. Darmendrail, Present-day vertical displacements in the north-western Alps and the southern Jura Mountains: data from leveling comparisons, Tectonics 14 (3) (1995) 606-616.

[14] A.O. Pfiffner, S. Sahli, M. Stäuble, Structure and evolution of the external basement massifs (Aar, Aiguilles Rouges/Mt. Blanc), in: O.A. Pfiffner, P. Lehner, P.Z. Heitzman, S. Mueller, A. Steck (Eds.), Deep Structure of the Swiss Alps - Results from NRP 20, Birkhäuser, Basel, 1997, pp. 139-153.

[15] F. Waldhauser, E. Kissling, J. Ansorge, S. Mueller, Threedimensional interface modelling with two-dimensional seismic data: the Alpine crust-mantle boundary, Geophys. J. Int. 135 (1998) 264-278.

[16] G.H. Gudmundsson, An order-of-magnitude estimate of the current uplift-rates in Switzerland caused by the Würm Alpine deglaciation, Eclogae Geol. Helv. 87 (2) (1994) 545-557.

[17] J. Mosar, Folds and thrust in the Préalpes Médianes plastiques romandes, Bull. Soc. Vaudoise Sci. Nat. 84 (4) (1997) 347-384.

[18] W. Wildi, P. Huggenberger, Reconstitution de la plate-forme européenne anté-orogénique de la Bresse aux Chânes subalpines: éléments de cinématique alpine (France et Suisse occidentale), Eclogae Geol. Helv. 86 (1) (1993) 47-64.

[19] J.P. Platt, Dynamics of orogenic wedges and the uplift of high-pressure metamorphic rocks, Geol. Soc. Am. Bull. 97 (1986) 1037-1053.

[20] A. Sommaruga, Décollement tectonics in the Jura foreland fold-and-thrust belt, Mar. Pet. Geol. 16 (1999) 111-134.

[21] A. Sommaruga, Geology of the Central Jura and the Molasse Basin: new insight into an evaporite-based foreland fold and thrust belt, Mém. Soc. Neuchâtel. Sci. Nat. 12 (1997) 176.

[22] M. Burkhard, A. Sommaruga, Evolution of the Swiss Molasse basin: structural relations with the Alps and the Jura belt, Geol. Soc. London, Spec. Publ. 134 (1998) 279-298. 
[23] H.P. Laubscher, Jura Mountains, in: D.J., K.A., S.R. (Eds.), Gravity and Tectonics, Wiley, New York, 1973, pp. 217227.

[24] H.P. Laubscher, Die Fernschubhypothese der Jurafaltung, Eclogae Geol. Helv. 54 (1961) 221-280.

[25] J. Braun, C. Beaumont, Three-dimensional numerical experiments of strain partitioning at oblique plate boundaries: implications for contrasting tectonic styles in the southern Coast Ranges, California, and central South Island, New Zealand, J. Geophys. Res. 100 (B10) (1995) 18050-18074.

[26] S.M. Schmid, A.O. Pfiffner, N. Froitzheim, G. Schönborn, E. Kissling, Geophysical-geological transect and tectonic evolution of the Swiss-Italian Alps, Tectonics 15 (5) (1996) 1036-1064.

[27] R.H. Marchant, G.M. Stampfli, Crustal and lithospheric structures of the Western Alps: geodynamic significance, in: O.A. Pfiffner, P. Lehner, P.Z. Heitzman, S. Mueller, A. Steck (Eds.), Deep Structure of the Swiss Alps - Results from NRP 20, Birkhäuser, Basel, 1997, pp. 326-337.

[28] J. Mosar, G.M. Stampfli, F. Girod, Western Préalpes médianes: timing and structure. A review, Eclogae Geol. Helv. 89 (1) (1996) 389-425.

[29] A. Sommaruga, Tectonics of the Central Jura and the Molasse Basin. New insight from the interpretation of seismic reflection data, Bull. Soc. Neuchâtel. Sci. Nat. 118 (1995) 95-108.

[30] Y. Philippe, B. Coletta, E. Deville, A. Mascle, The Jura fold-and-thrust belt: a kinematic model based on mapbalancing, in: P.A. Ziegler, F. Horvath (Eds.), Peri-Tethys Memoir 2: Structure and Prospects of Alpine Basins and Forelands, 170, Mém. Muséum Natl. Hist. Nat., Paris, 1996, pp. 235-261.

[31] D. Aubert, Le décrochement de Pontarlier et l'orogenèse du Jura, Mém. Soc. Vaudoise Sci. Nat. 12 (4) (1959) 93-152.

[32] J. Charollais, B. Clavel, E. Amato, A. Escher, R. Busnardo, N. Steinhauser, O. Macsotay, P. Donzé, Etude préliminaire de la faille du Vuache (Jura méridional), Bull. Soc. Vaudoise Sci. Nat. 76 (3) (1983) 217-256.

[33] N. Pavoni, Faltung durch Horizontalverschiebung, Eclogae Geol. Helv. 54 (2) (1961) 515-534.

[34] M. Burkhard, Aspects of large-scale Miocene deformation in the most external part of the Swiss Alps (Subalpine Molasse to Jura fold belt), Eclogae Geol. Helv. 83 (3) (1990) 559-584.

[35] J. Charollais, M. Jamet, Principaux résultats géologiques du forage Brizon 1 (BZN 1) Haute-Savoie, France, Mém. Soc. Géol. Fr. 156 (1990) 185-202.

[36] C. Signer, G.E. Gorin, New geological observations between the Jura and the Alps in the Geneva area, as derived from reflection seismic data, Eclogae Geol. Helv. 88 (2) (1995) 235-265.

[37] G.E. Gorin, C. Signer, G. Amberger, Structural configuration of the western Swiss Molasse Basin as defined by reflection seismic data, Eclogae Geol. Helv. 86 (3) (1993) 693-716.

[38] P. Diebold, T. Noack, Late Paleozoic troughs and Tertiary structures in the eastern folded Jura, in: O.A. Pfiffner, P.
Lehner, P.Z. Heitzman, S. Mueller and A. Steck, (Eds.), Deep Structure of the Swiss Alps - Results from NRP 20, Birkhäuser, Basel, 1997, pp. 59-63.

[39] M. Jaboyedoff, M.A. Cosca, Dating incipient metamorphism using ${ }^{40} \mathrm{Ar} /{ }^{39} \mathrm{Ar}$ geochronology and XRD modeling: a case study from the Swiss Alps, Contrib. Mineral. Petrol. 135 (2) (1999) 93-113.

[40] J. Mosar, Métamorphisme transporté dans les Préalpes, Schweiz. Mineral. Petrogr. Mitt. 68 (1) (1988) 77-94.

[41] J. Mosar, G. Borel, Paleostress from the Préalpes médianes (Switzerland), Ann. Tectonicae 6 (2) (1992) 115-133.

[42] D. Raymond, B. Deffontaines, A. Fehri, J.-M. Dorioz, J.-P. Rudant, Néotectonique de la région sud-lémanique (Hautesavoie, France): approche multisources (imagerie optique et hyperfréquences, analyse morphostructurale), Eclogae Geol. Helv. 89 (3) (1996) 949-973.

[43] E. Rüttner, Earthquake hazard evaluation for Switzerland, Contributions to the Geology of Switzerland, Geophysics 29 (1995) 150.

[44] H.R. Maurer, Seismotectonics and Upper Crustal Structure in the Western Swiss Alps, Diss. ETH 10268, Swiss Federal Institute of Technology, Zürich, 1993.

[45] B. Delouis, H. Haessler, A. Cisternas, L. Rivera, Stress tensor determination in France and neighbouring regions, Tectonophysics 221 (1993) 413-437.

[46] U. Sambeth, N. Pavoni, A seismotectonic investigation in the Geneva Basin, southern Jura mountains, Eclogae Geol. Helv. 81 (1988) 433-440.

[47] F. Thouvenot, J. Fréchet, P. Taponnier, J.-C. Thomas, B. Le Brun, G. Ménard, R. Lacassin, L. Janetton, J.-R. Grasso, O. Coutant, A. Paul, D. Hatzfeld, The Ml 5.3 Epagny (French Alps) earthquake of 1996 July 15: a long-awaited event on the Vuache fault, Geophys. J. Int. 135 (1998) 876-892.

[48] M. Tardy, E. Deville, S. Fudral, S. Guellec, G. Ménard, F. Thouvenot, P. Vialon, Interprétation structurale des données du profil de sismique réflexion profonde Ecors-Crop Alpes entre le front Pennique et la ligne du Canavese (Alpes occidentales), in: F. Roure, P. Heitzmann, R. Polino (Eds.), Deep Structure of the Alps, Mém. Soc. Géol. Fr. 156 (1990) 217-226.

[49] A. Steck, J.L. Epard, A. Escher, P. Lehner, R.H. Marchant, H. Masson, Geological interpretation of the seismic profiles through Western Switzerland: Rawil (W1), Val d'Anniviers (W2), Mattertal (W3), Zmutt-Zermatt-Findelen (W4) and Val de Bagnes (W5), in: O.A. Pfiffner, P. Lehner, P.Z. Heitzman, S. Mueller, A. Steck (Eds.), Deep Structure of the Swiss Alps - Results from NRP 20, Birkhäuser, Basel, 1997, pp. 123-138.

[50] A. Montrasio, R. Bersezio, F. Forcella, F. Jadoul, E. Sciesa, Geological interpretation of the profile CROP - Central Alps (Passo Spluga - Bergamo), Quad. Geodin. Alpina Quat. 2 (1994) 171-186.

[51] F.A. Dahlen, J. Suppe, Mechanics, growth and erosion of mountain belts, Geol. Soc. Am. Spec. Pap. 218 (1988) 161178.

[52] E. Banda, S. Cloetingh, Europe's lithosphere - physical properties of the lithosphere, in: D. Blundell, R. Freeman, 
S. Mueller (Eds.), A Continent Revealed - The European Geotraverse, University Press, Cambridge, 1992, pp. 71-79.

[53] S.D. Willett, Dynamic growth and change of a Coulomb wedge, in: McClay (Ed.), Thrust Tectonics, Chapman and Hall, London, 1992, pp. 19-31.

[54] O.A. Pfiffner, Molasse basin tectonics and its relation to the Jura mountains, in: O.A. Pfiffner, P. Lehner, P.Z. Heitzman, S. Mueller, A. Steck (Eds.), Deep Structure of the Swiss Alps - Results from NRP 20, Birkha “user, Basel, 1997, pp. 71-72.

[55] J. Fréchet, F. Thouvenot, L. Janetton, P. Hoang-Trong, M.
Frogneux, Le séisme du Grand-Bornand (Haute-Savoie) du décembre 1994: un coulissage dextre dans le socle subalpin, C.R. Acad. Sci. (Paris), Sér. II 323 (1996) 517-524.

[56] M. Burkhard, L'Helvétique de la bordure occidentale du massif de l'Aar (évolution tectonique et métamorphique), Eclogae Geol. Helv. 81 (1) (1988) 63-114.

[57] E. Gubler, S. Arca, J. Kakkuri, K. Zippelt, Recent crustal movements, in: R. Freeman, S. Mueller (Eds.), Atlas of Compiled Data - A Continent Revealed - the European Geotraverse, University Press, Cambridge, 1992, pp. 20-25. 